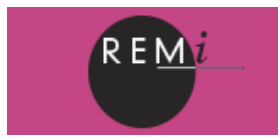

Revue européenne des migrations internationales

vol. $35-n^{\circ} 1$ et $2 \mid 2019$

Asia Pacific Migration

\title{
Migration to Australia: From Asian Exclusion to Asian Predominance
}

Migration vers l'Australie: de l'exclusion des Asiatiques à leur prédominance

Migración a Australia: de la exclusión de los asiáticos a su predominio

\section{Peter McDonald}

\section{(2) OpenEdition}

Electronic version

URL: https://journals.openedition.org/remi/12695

DOI: $10.4000 /$ remi. 12695

ISSN: $1777-5418$

\section{Publisher}

Université de Poitiers

\section{Printed version}

Date of publication: 1 October 2019

Number of pages: 87-105

ISBN: 979-10-90426-64-1

ISSN: 0765-0752

\section{Electronic reference}

Peter McDonald, "Migration to Australia: From Asian Exclusion to Asian Predominance", Revue européenne des migrations internationales [Online], vol. 35 - $n^{\circ} 1$ et 2 | 2019, Online since 01 January 2021, connection on 14 April 2022. URL: http://journals.openedition.org/remi/12695 ; DOI: https:// doi.org/10.4000/remi. 12695 


\title{
Migration to Australia: From Asian Exclusion to Asian Predominance
}

\author{
Peter McDonald ${ }^{1}$
}

This paper traces how Australia has shifted from being a country where migration from Asia was heavily restricted to one where most of the immigrants arriving in a very large migration programme are from Asia and most of the new permanent residents are from Asia. At the 1961 Census of Australia, $0.3 \%$ of the Australian population were of Asian racial origins and the number of Asians in Australia was lower than it had been in 1861 (Commonwealth Bureau of Census and Statistics, 1967; Choi, 1975). In sharp contrast, $26 \%$ of all births in Australia in 2016 had at least one parent born in Asia (Australian Bureau of Statistics, 2017). Historically, the restriction of entry of Asians to Australia was based upon two broad considerations: 1 . a sense of racial superiority and racism and 2 . a fear of large numbers of Asians and the ensuing labour market competition. Changes in Asian migration across time are examined in the context of these two considerations. The paper demonstrates the central role that the international student programme has played in the process of change in the twenty first century.

\section{Background: Australia's Historical Restriction of Immigration from Asia}

\section{Initial Restriction: The 1850s Gold Rush}

For most of the time following British settlement of Australia, Asian migration to Australia was looked upon unfavourably. Attempts in the 1840s to introduce Chinese coolie labours, modelled on the approaches used in Malaya and Indonesia, failed partly because of opposition from Australian workers. The restrictive approach to Asian migration began in earnest in the 1850s during the gold rush in the Colony of Victoria. Although miners arrived in the new colony of Victoria from all over the world, restrictions on landing in the colony were placed only upon the Chinese. Prior to the restrictions implemented in 1855, Chinese miners from the Canton region of China had arrived in large numbers and by mid-1855 the Chinese population of Victoria had risen to 15,000, almost all of whom were men. The restrictions imposed by the Colony of Victoria were circumvented immediately by Chinese arriving in the neighbouring colonies

1 Professor of Demography, Melbourne School of Population and Global Health, University of Melbourne, Victoria 3010 Australia, Room 521a, Level 5, 207 Bouverie Street Carlton, Melbourne, Australia; mcdonald.p@unimelb.edu.au 
of New South Wales and South Australia and then walking to the gold fields in Victoria. Around 15,000 Chinese immigrants arrived at the port of Guichen Bay in South Australia in the first six months of 1857. Subsequently, due to lobbying from Victoria, restrictions were placed upon Chinese migration in South Australia in 1857 and in New South Wales in 1861. The 1861 Act in New South Wales followed the Lambing Flat riot when Chinese were run off their mining sites. Across Australia, in 1861, there were 38,247 China-born men and eleven China-born women constituting about 3.2\% of the total population (Choi, 1975).

The account in the previous paragraph derives largely from Choi (1975). Choi considers that opposition to Chinese migration in the 1850s was due mainly to the large numbers arriving simultaneously and the competition that the new arrivals imposed upon other miners. He also refers to the cultural distance between the Chinese and other settlers. While there may be a fine line between the concept of cultural distance and racism, Choi suggests that the opposition was not purely motivated by racism. The anti-Chinese migration Acts were repealed relatively rapidly, in South Australia in 1861, in Victoria in 1865 and in New South Wales in 1867, when the movement from China had slackened off tending to support Choi's view that the restrictions were driven more by economic motivations than by racism. With the corporatisation of mining in Australia from the 1860s, it was easier to exclude Chinese workers.

\title{
The Development of the White Australia Policy
}

Nevertheless, very negative portrayals of Chinese people in the popular press in the second half of the nineteenth century were clearly racist and, although the China-born population of Australia fell between 1861 and 1901, the blatantly racist, White Australia Policy was one of the first Acts to be passed by the newly constituted Government of the Commonwealth of Australia in 1901. The following statements were made during the 1901 debate on the Act by members of the first parliament who became the first four Prime Ministers of Australia2:

"We should pass this bill to secure the future of our fair country against the tide of inferior and unequal Asians arriving from the north, threatening the prospects for white Australians."(Edmund Barton)

"This bill does not go far enough. Asian immigration is only one element of the 'coloured alien' problem. Later I will suggest that we change the bill to exclude any person who is an aboriginal native of Asia,

Africa or of the Pacific Islands." (John Watson)

"We have all seen the problem caused by coloured people in the United States.

We do not want that to happen here. The Opposition wants the new Australia to be a land for the finest products of the Anglo-Saxon race.

This Bill will make that happen." (George Reid)

\begin{abstract}
"I argue for the YES vote on this bill to restrict Asian immigration not because Asians are unequal and inferior but because of their high abilities. The Asian races threaten our life style. They take our comfortable jobs and are prepared to accept conditions inferior to those we have become accustomed to."(Alfred Deakin)
\end{abstract}

2 Parliamentary Education Office, Immigration Restriction Act 1901, https://web.archive. org/web/20051022064554/http://www.peo.gov.au/resources/immigration_bill.htm 
The two restrictive themes are evident in these statements by politicians: assumed racial superiority and racism (more likely to be expressed by the conservative side of politics, Barton and Reid) and fear of labour market competition (more likely to be expressed by the left side of politics, Watson and Deakin).

\section{Abolition of the White Australia Policy}

As stated above, there were very few Asians in Australia in 1961 indicating that the White Australia policy had been applied rigidly in the previous sixty years. However, the experiences of the Second World War and, more importantly, the emergence of new post-colonial nations to Australia's north focussed official attention in Australia much more upon the politics of Asia than had been the case in the pre-war years. In 1949, Australia had been the leading international supporter of independence for Indonesia. Gradually, the White Australia Policy was seen to be an embarrassment for a country wishing to establish good diplomatic relations with its Asian neighbours and Australia's Asian neighbours were not backward in drawing attention to the restrictive migration policy. International students were a prominent part of the process of opening Australia to migration from Asia. From 1950 onwards, Asian students came to Australia privately and under the government-funded Colombo Plan. Oakman argues that the experiences of Asian students in Australia and Australians' experiences of them were a significant factor in the ending of the White Australia Policy:

"Although the number of Asian scholars was small, their presence marked something of a watershed in Australia's cultural development, and their appearance on university campuses and in private homes across the country provided a direct if subtle — challenge to Australian insularity." (Oakman, 2002: 98)

In establishing a review of Australian immigration policy in 1966, Harold Holt referred to the impact of the 12,000 Asian students then studying in Australia (Commonwealth Parliamentary Debates, 8 March 1966, Vol. 50, p. 34). Restrictions on migration from Asia were eased following this review and the White Australia Policy was finally removed totally by the Whitlam Labour Government in 1972. From that point, the use of race, colour or creed in migrant selection became part of history.

The commitment to a non-white Australia was immediately tested through the arrival of very large numbers of refugees from Vietnam and Lebanon in the 1970s and 1980s. By 1996, there were 151,000 Vietnam-born persons in Australia and 70,000 Lebanon-born persons in a total of just over 1 million people born in an Asian country, representing $5.5 \%$ of the Australian population (derived by the author from data in ABS 2007). This was already a major transformation from the $0.3 \%$ of the Australian population that Asians constituted in 1961 but migration policy changes after 1996 have led to much larger numbers of migrants from Asia. 


\section{Revived Restrictive Movements: One Australia, One Nation and Australia First}

Opposition to Asian migration arose not very long after the elimination of the White Australia Policy. In 1984, the prominent Australian historian, Geoffrey Blainey, stated that the influx of Asians was threatening the social fabric, giving a degree of respectability to this viewpoint. In 1988, as Leader of the Opposition, John Howard developed the One Australia policy. The policy called for an end to multiculturalism thus ending (temporarily) the bipartisan approach to settlement of immigrants in Australia. While Howard's speech inaugurating the One Australia policy did not refer to migration from Asia, his subsequent comments on radio and those of his Coalition colleagues, John Stone and Ian Sinclair, were explicitly anti-Asian migration. On the ABC PM programme, Howard called for Asian migration to be reduced. Most explicitly, Sinclair, the Shadow Deputy Prime Minister at the time said:

"If there is any risk of an undue build-up of Asians against others in the community, then you need to control it. I certainly believe that at the moment we need [...]

to reduce the number of Asians." (Markus, 2001: 85-89)

Prominent members of Howard's own party publicly opposed the sentiments of One Australia. These included Malcolm Fraser, Nick Greiner, Jeff Kennett, Steele Rudd and Ian McPhee. The then Labour Prime Minister, Bob Hawke, was quick to demonstrate the division in the Opposition parties over One Australia. He moved a motion in the parliament rejecting the use of race to select immigrants, to confirm the status quo. Howard voted against the motion but three Liberal MPs voted with the Labour Government (Ramsey, 2006). In his autobiography published in 2010, Howard wrote that he was wrong to have said in 1988 that Asian immigration had outstripped community tolerance but the context of the statement suggests that he was more concerned about the impact that the statement had had on his political career; that he was wrong to have made the statement rather than that his statement was wrong. In the same book, he claims that, as Prime Minister, he kept the lid on the newly-emergent anti-Asian migration movement in the form of Pauline Hanson's One Nation Party (Howard, 2010). In a speech in London on 27 June 2018, Howard is quoted as saying: "1 million of Australia's population [...] are ethnic Chinese background. [They are] terrific citizens making an enormous contribution to our nation" (The Age, 28 June 2018). Prior to the 1996 election, Pauline Hanson was dis-endorsed as the Liberal Party candidate for the seat of Oxley because of disparaging comments she had made about indigenous Australians. She then ran as an independent candidate and was elected to the House of Representatives in 1996. Famously, in her maiden speech, she said that she believed that "we are in danger of being swamped by Asians" citing, correctly, that, between 1984 and 1995, 40\% of new immigrants had come from Asian countries.

At the time, Hanson was advised by John Pasquarelli to "go for broke on Asian immigration" (Pasquarelli, 1998: 10). Pasquarelli had been an adviser to Senator John Stone, avid supporter of Howard's One Australia policy and went on to be an adviser to the Labour MP, Graeme Campbell, who founded the Australia First Party, the loudest contemporary voice against Asian migration. Thus, there was a connection between these three anti-Asian migration movements across thirty 
years (Dorling, 2017). In her return to parliament in 2016 as a Senator, Pauline Hanson has made anti-Muslim migration statements but not anti-Asian statements. According to Dorling (2017), this is because anti-Asian migration has less political traction in contemporary Australia. When asked by a journalist whether she stood by her 1996 statement that Australia was being swamped by Asians, Hanson referred to just one suburb in Sydney, Hurstville, as evidence to support what she had said in $1996^{3}$.

In 2018, organised opposition to Asian migration tends to be confined to the extreme right, especially the Australia First Party. Being on the extreme fringe, this party expresses its views very forthrightly calling for the reinstatement of the White Australia Policy and inviting all non-White Australians to leave Australia permanently.

The One Australia and One Nation opposition to Asian migration was related to fear that large numbers of Asian immigrants threatened Australia's way of life, not to the fear that Asians would take the jobs of Australians. The fear, therefore, was socially-based rather than economically-based. Expansion of Asian migration after 1996 has, in contrast, been driven by economic motivations, principally, a continuing strong demand for skilled labour, ironically driven to a large extent by the rise of China as Australia's most important economic trading partner. The remainder of the paper documents how this shift to a dominance of Asian sources in Australia's migration programme has occurred.

\section{Asian Migration to Australia, 1996-2017}

In $1996,5.5 \%$ of the Australian population had been born in an Asian country. By 2016 , this had risen to $13.4 \%$, constituting close to half of the overseas-born population. Between the 2011 and 2016 Censuses, the increase in the Asianborn population of Australia was equivalent to $85 \%$ of the net increase in the total overseas-born population, and this percentage rose to $99 \%$ for the cities of Sydney and Melbourne. These high percentages apply because, for non-Asian countries of birth, the intercensal increases were offset by mortality due to deaths of the European migrants who arrived in the early post Second World War period. Between 1996 and 2016, the population born in China (not including SARs) increased from 111,000 to 510,000 and, for those born in India, from 78,000 to $455,000^{4}$. And, as mentioned above, $26 \%$ of all births in Australia in 2016 had at least one Asian-born parent. These are startling changes in a country historically not far away from a policy of exclusion of all Asians. The changes have not occurred because there has been a deliberate preference for migrants from Asia. Rather, substantial Asian migration has been the outcome of a range of policy settings that have had the effect of shifting the migration programme towards movement from Asia.

3 http://www.abc.net.au/news/2016-09-14/pauline-hanson-maiden-speech-asian-immigration/7645578

4 Numbers cited here are derived by the author from statistics of country of birth published by the Australian Bureau of Statistics from Australian censuses for the years, 1996 to 2016. 


\section{International Migration Definitions and Trends since 1983}

\section{Definitions of International Migration}

There are two measures of international migration that are often confused in popular discussion. The first is the government's Permanent Migration Programme. Set annually by the government, the programme indicates the planned new grants of permanent residence in Australia in a financial year. These grants of permanent residence divide into three streams: Skilled Workers, Family and Humanitarian. The second measure is Net Overseas Migration (NOM). This is the number by which the usual resident population of Australia changes in a year consequent upon international migration. The two measures are fundamentally different. NOM includes many movements that are not part of the Migration Programme. It is the net result of movements into and out of Australia of temporary residents, movements into and out of Australia of Australian and New Zealand citizens and the permanent arrivals and departures of citizens of countries other than Australia and New Zealand. Furthermore, the one component of NOM that may be thought to mirror the Migration Programme, permanent arrivals of citizens of countries other than Australia and New Zealand, differs substantially from the numbers in the Migration Programme in the same year because, in recent years, about half of the grants of permanent residence through the Migration Programme are made to people who are already temporary usual residents of Australia, that is, they have already been counted into NOM at some previous time.

The census numbers cited in the previous section relate to the usual resident population of Australia. Usual residents include persons who do not have permanent residence in Australia but are counted as usual residents because of the duration of their stay in Australia (or absence from Australia). From 1983 to mid-2006, from the perspective of international migration, a person was a resident of Australia if they had lived in Australia continuously for the past twelve months or had not been absent from Australia for a continuous twelvemonth period. This definition meant that many long-term temporary residents were not counted as usual residents because they had been out of Australia recently for even a short period. For example, international students undertaking a university degree in Australia would not have been counted as usual residents if they had gone home during a university break. As another example, many skilled temporary workers, although resident in Australia for some number of years would not have been counted in the population if they were frequently out of Australia on business.

Because this approach was regarded as under-counting the population of usual residents of Australia, from July 2006, the Australian Bureau of Statistics has applied a different definition. From that time, a person is a usual resident if he or she has spent twelve out of the past sixteen months in Australia. This is measured through monitoring of passport movements. While this approach implies that there is a sixteen-month delay before it can be determined whether a person should be counted into or out of the population (that is, the movement included in NOM), the Australian Bureau of Statistics uses a statistical model to predict whether or not a new arrival will later be counted into the population 
(or a departure counted out) based on certain characteristics of the person. If the ABS model predicts that the movement is a movement of a usual resident, the movement is included in NOM at the time that it occurs. So, for example, a student from China newly arriving in Australia to take up a three-year undergraduate degree in Australia is extremely likely to be counted into the usual resident population from the date of arrival.

The change in definition in 2006 coincided with a large increase in temporary movements to Australia, especially of international students. As a large percentage of international students come from Asia, the change in definition has meant that, since 2006, most of these students have been counted as usual residents of Australia (the numbers are discussed below).

Despite the substantial conceptual differences between the Permanent Migration Programme and Net Overseas Migration, Figure 1 shows that the two numbers are very similar. This result occurs mainly because, in the longer term, temporary residents who are not Australian or New Zealand citizens have to leave unless they attain permanent residence through the Migration Programme. A second reason for the similarity of the two numbers is that the net movement of Australian citizens, permanent residents and New Zealand citizens is close to zero in the longer term, effectively because the net gain of New Zealand citizens matches the net loss of Australian citizens and permanent residents. Wide fluctuations of NOM compared with the Programme numbers indicate years in which there are surges in temporary arrivals as occurred around 2008-09.

Figure 1: Annual Net Overseas Migration (NOM) Compared with the Annual Grants of Permanent Residence through the Permanent Migration Programme

(Australia, 1983-84 to 2015-16)

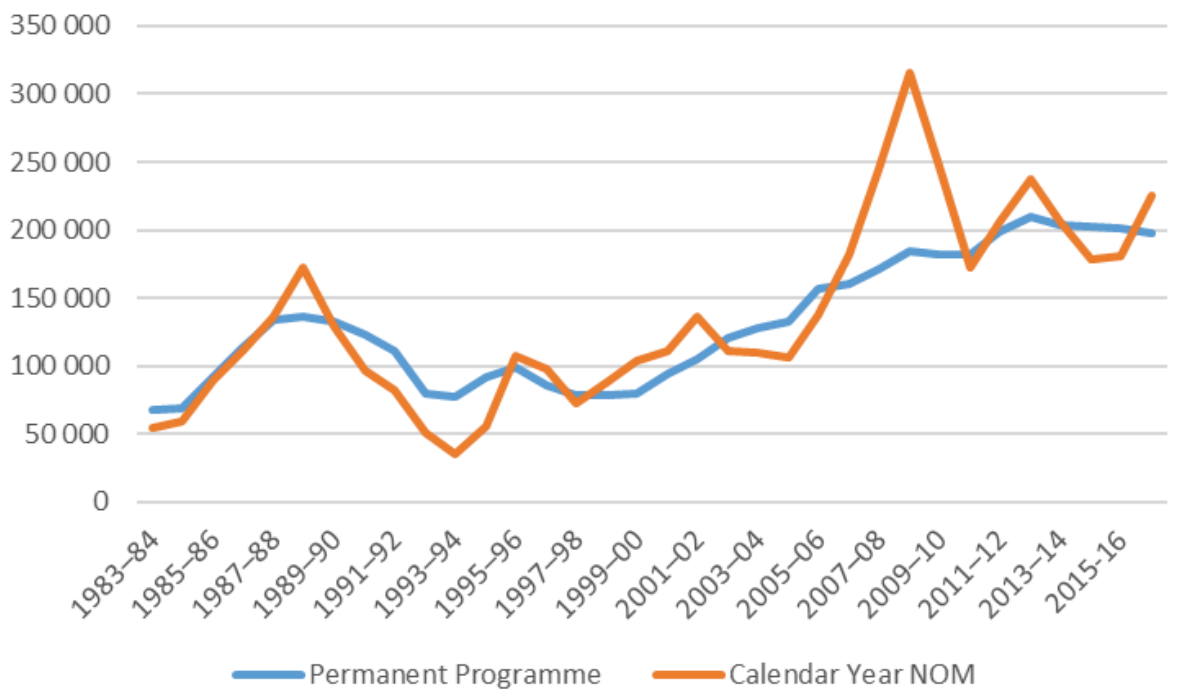

Sources: Department of Home Affairs (Permanent Programme Numbers); Australian Bureau of Statistics (NOM numbers). 


\section{Trends in International Migration}

Figure 1 shows that Net Overseas Migration averaged around 100,000 per annum prior to the change in definition that occurred in 2006 after which it has averaged close to 200,000 per annum. In accordance with the view that the Permanent Migration Programme is the fundamental driver of Net Overseas Migration in the longer term, the programme level rose correspondingly from 80,000 in the year 2000 to 210,000 in 2012 after which it has remained at about that level. The combined Skill and Family Stream levels in the Migration Programme were set at 190,000 in the 2012-13 financial year and this same number has been held constant to 2018-19. Since 2012-13, there have been some small fluctuations in the Humanitarian Stream but there was a large increase in 2016-17 of about 10,000 persons from Syria and Iraq.

Thus, for the purposes of this paper, the increase in the Asia-born population of Australia can have two components: (a) changes in the number of Asians who are long-term temporary residents of Australia, notably students and (b) changes in the numbers of Asians who are permanent residents (and citizens) of Australia. Before discussing these possibilities in more detail, as background, it is important to consider the underlying policy changes.

\section{Permanent and Temporary Skilled Migration: Significant Policy Changes from 1995 Onwards}

\section{Policy Shift to Skilled Migration}

In 1995, international migration policy was changed in two important ways. First, a points system was introduced in the selection of new permanent residents with the points being determined by the skill level of the applicant, and entry was limited to those with higher-level skills. Points were awarded for qualifications, work experience, age and English proficiency. Second, in a global economy in which there is a global labour market for those with the highest skills, the view was taken that a more comprehensive and efficient form of temporary skilled migration was required. Importantly, the temporary skilled migration scheme provided a central role for employer sponsorship in the migration programme by providing a streamlined approach in a market where speed plays an important role. When these changes were made in 1995, the skilled permanent and the skilled temporary visa programmes were conceived as largely unrelated entities. Since then, however, they have gradually been merging into a single system in which permanent migration is often preceded by a period of temporary migration. This has been achieved through a series of changes in practice that have enabled applicants for permanent migration in the skill stream to nominate or be nominated while onshore in Australia.

\section{Application for Permanent Residence Onshore}

The perceived success of the merging of temporary and permanent skilled migration and continuing strong demand for labour in Australia led to a further evolution that enabled international students and working holiday makers (backpackers) to nominate for permanent residence onshore through the skilled stream. Alternatively, international students and working holiday makers took 
up employment in Australia via a temporary skilled worker visa (subclass 457) with the aim of later transitioning to permanent residence. This 'two-step' strategy has been evaluated favourably (Hawthorne, 2010).

In 2014-15, 129,000 people were granted permanent residence in the Skill Stream but only 42,300 people were counted into the Australian population as new arrivals on a Skill Stream visa. This is because the others granted permanent residence in the Skill Stream had already been counted into the Australian population under a temporary visa category before their permanent residence was granted. In the same year, net migration (NOM) to Australia was 179,000. Of this number, 131,000 (73\%) were people holding some form of temporary residence visa at the time they were counted into the population.

In 2016-17, the three main eligibility categories (employer nominated, skilled independent and state or territory nominated) constituted $93 \%$ of the permanent skilled migration programme. Close to $60 \%$ of persons obtaining permanent residence in these categories had applied onshore and for the largest category, employer sponsored, $86 \%$ had applied onshore mainly from a temporary skilled migration visa (Department of Immigration and Border Protection, 2017; Figure 2).

\section{International Students: Significant Policy Changes from 1998 Onwards}

The Parliamentary Library has prepared an excellent overview of policy changes relating to international students from 1997 to 2015 (Department of Parliamentary Services, 2016). In 1998, the Howard Government began a campaign to increase the number of international students studying in Australia to enhance Australia's foreign earnings and to provide an alternative funding source for Australian universities. Since that time, foreign income from international students has risen to become Australia's third largest export in value after iron ore and coal and around $20 \%$ of the income of Australian universities comes from international student fees (DET, 2015), only slightly below the fee income from Australian students. At least for some international students, the prospect of permanent residence in Australia is a motivation to choose to study in Australia. Thus, the potential for permanent residence in Australia is part of the marketing strategy for this important industry.

To facilitate the increase of international students studying in Australia while maintaining the integrity of the system, successive Australian governments have made frequent changes to the migration requirements associated with international students (DET, 2015). The main changes that have contributed to additional immigrant stocks and flows from Asia are as follows:

- The points test used to select skilled migrants is modified to grant five additional points where an applicant has obtained their diploma, trade certificate or degree from an Australian educational institution (July 1999). Later, the additional points were increased to ten for Honours and Masters graduate and to fifteen for PhD graduates (March 2003).

- Certain groups of successful Australian-educated overseas students with key skills, particularly ICT qualifications, are able to apply and be granted permanent 
residence visas under the Skilled-Independent and related categories without leaving Australia (July 2001).

- A new student guardian visa is introduced to allow parents and other relatives to care for international students in Australia (December 2003).

- Overseas students are able to apply, on completion of their studies in Australia, for an Occupational Trainee Visa to undertake up to twelve months of supervised on-the-job training in their area of expertise (November 2005).

- Graduating international students in certain disciplines are able to apply for a Subclass 485 visa to enable them to remain in Australia for a period of eighteen months to find work in their occupation and improve their English skills (September 2007). Following the Knight review in 2011, this right was extended to all graduating students in Higher Education and increased to two years for a Bachelor degree, three years for Master degree and four years for A PhD degree so long as the applicant's first visa to study in Australia was granted on or after 5 November 2011. This change was directed explicitly at improving Australia's position in the international market for students.

- Overseas students are granted the automatic right to work up to twenty hours per week under their student visas while their course is in session (April 2008). Prior to this, students had to apply for these work rights.

- Massive expansion in 2008 and 2009 of students particularly from South Asia undertaking short courses in mainly private educational institutions with a view to applying for permanent residence in Australia. Many of these educational institutions were merely money-making ventures and, in 2009, many went out of business. This movement distorted the Skill Stream such that almost all new permanent residence visas in the Skill Stream were in the relatively low-level skills of cooks, hairdressers and accountants. This movement was checked in February 2010 with the removal of cooks and hairdressers from the occupation eligibility list for the General Skilled Migration category (MODL).

- Then current students in the short-course category just described whose occupation was not on the new list of eligible occupations for permanent residence in the General Skilled Migration category (the Skilled Occupation List, or SOL) were permitted to apply for a temporary skilled graduate visa enabling them to spend up to 18 months in Australia to acquire work experience and find an Australian employer willing to sponsor them on completion of their course. Employer sponsorship was available across a very much wider range of occupations (the Consolidated Skilled Occupations List, or CSOL) which included cooks and hairdressers (February 2010).

- At various times across these years, the visa processing requirements were simplified to facilitate ease of entry.

The effect of these changes upon grants of visas to international students is shown in figure 2. The number of grants rose from 111,000 in 1998-99 to 191,000 in 2005-06. With a surge in numbers taking short courses, grants hit 320,000 in 2008-09. The subsequent crackdown on short course students reduced the numbers to around 250,000 but a new surge began from 2013-14 onwards. The new surge was in the university sector and followed the changes made to the Temporary Graduate visa (subclass 485). In the latest year, 2016-17, the number of international student grants hit a new high point at 343,000. At the end of May 2018 , there were 561,000 international students in Australia and 71,000 sub-class 485 graduate visa holders, a total equivalent to one in every fourty persons in Australia (Department of Home Affairs, 2018). 
Figure 2: International Student Visa Grants (Australia, 1996-97 to 2016-17)

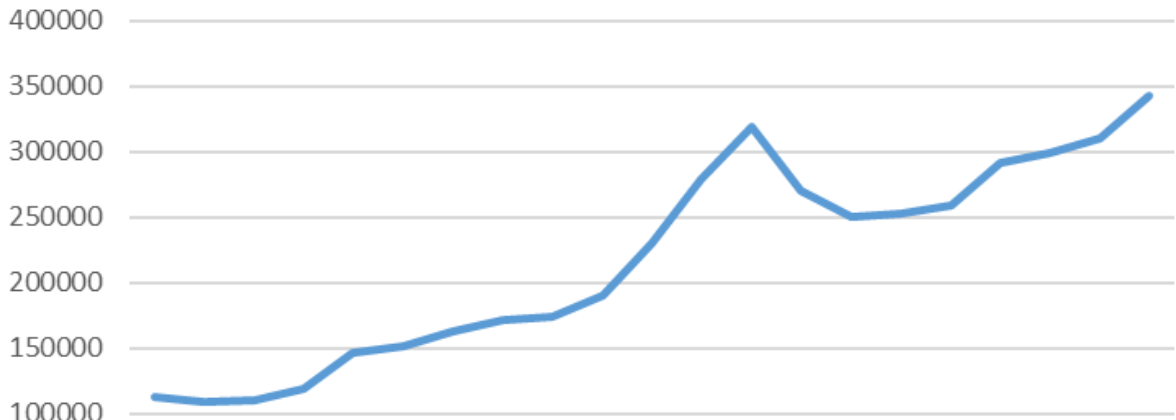

50000

0

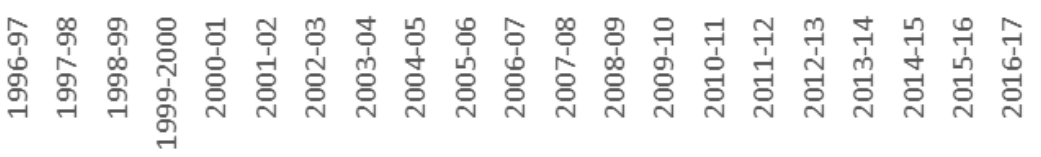

Source: Department of Home Affairs, 2018.

\section{The Components of Net Overseas Migration}

The shift to measurement of migration based on passport movements has enabled the visa types of migrants crossing Australia's border to be identified. Thus, it is possible to divide net overseas migration into the movements of each visa type. For each movement into or out of Australia, the Australian Bureau of Statistics, using data files provided by the Department of Home Affairs, monitors whether individuals remain in or stay out of Australia for twelve out of the sixteen months following the border crossing. If it is a movement into Australia and the person subsequently is resident in Australia for twelve out of the next sixteen months, this is termed a NOM Arrival. The usual resident who remains out of Australia for twelve out of the next sixteen months is termed a NOM Departure. Net Overseas Migration is then the net of NOM Arrivals and NOM Departures. NOM Arrivals and NOM Departures are tagged with the visa type that the person held at the time of the border crossing upon which his or her NOM status was assessed. The country of citizenship of the mover is also captured along with a range of other characteristics such as age and sex.

Table 1 shows NOM Arrivals, NOM Departures and NOM summed over the twelve-year period, 2004-05 to 2015-16. The data are aggregated over twelve years so that annual fluctuations are smoothed. Each year, when the single number, Net Overseas Migration is published, there is much discussion and interpretation of movements up or down in the press and by the public. Table 1 shows that this single number, NOM, is the net outcome of numerous movement types into and out of the country. This makes interpretation of annual changes in NOM a complex matter. This is even more the case because annual data show that the movements for each visa type can vary considerably from the 
twelve-year averages shown in the table 1. For example, the table shows that the largest component of NOM over the eleven-year period is the net movement of international students at $31.2 \%$ of NOM, but in the final year, 2015-16, students composed $42.7 \%$ of NOM.

Overall, for the twelve years, $61 \%$ of NOM can be attributed to people on temporary visas, $34 \%$ to those on permanent residence visas and $5 \%$ to the combined net movements of New Zealand citizens and Australian citizens. Only $16 \%$ of NOM over the twelve years related to the Permanent Skill Stream, and more than half of these were the partners or children of the person whose skill was assessed. The continually controversial Temporary Skilled visa subclass (the 457 visa) accounted for only $10 \%$ of NOM over the twelve years and only $5.7 \%$ in $2014-15$. In contrast, the percentage of NOM related to Working Holiday Makers was high at $11.1 \%$.

Surprisingly, $13.5 \%$ of NOM related to people who had arrived on a Visitor visa. Almost all Visitor visas are issued for a period of just three months yet, over the eleven years, almost half a million people who arrived on a Visitor visa stayed in Australia for twelve out of the next sixteen months. To do this, these people must have shifted to another visa type that allowed them to stay longer. The main visa types to which those on Visitor visas transitioned (in net terms) were the Temporary Skilled visa and the Permanent Family visa (Department of Home Affairs and Department of the Treasury, 2018). Thus, they are likely to have been people arriving in Australia on a Visitor visa with an expectation of taking up one of these longer-term visas.

Table 1: Components of Net Overseas Migration by Visa/Movement Type (Australia, 2004-05 to 2015-16; 12-Year Aggregate)

\begin{tabular}{lcccc}
\hline \multicolumn{4}{l}{ Visa/Movement Type } & \multicolumn{3}{c}{ Visa Components of Net Overseas } & Migration, 2004-05 to 2014-15 \\
\hline & Arrivals & Departures & Net (N) & Net (\%) \\
\hline Permanent & $1,085,468$ & 220,812 & 864,656 & 34.0 \\
\hline Skilled & 503,424 & 92,815 & 410,609 & 16.2 \\
Family & 398,153 & 62,543 & 335,610 & 13.2 \\
Humanitarian & 130,453 & 1,665 & 128,788 & 5.1 \\
Other & 53,457 & 63,808 & $-10,351$ & -0.4 \\
\hline Temporary & $2,733,004$ & $1,187,117$ & $1,545,887$ & 60.8 \\
\hline Skilled & 416,795 & 170,739 & 246,056 & 9.7 \\
Student & $1,239,551$ & 447,445 & 792,106 & 31.2 \\
Working Holiday & 461,312 & 179,371 & 281,941 & 11.1 \\
Visitor & 529,629 & 185,910 & 343,719 & 13.5 \\
Other & 85,707 & 203,650 & $-117,943$ & -4.6 \\
New Zealand Citizens & 529,722 & 232,060 & 297,662 & 11.7 \\
Australian Citizen & 904,020 & $1,079,413$ & $-175,393$ & -6.9 \\
Other & 162,600 & 154,269 & 8,331 & 0.3 \\
\hline TOTAL & $5,414,814$ & $2,873,671$ & $2,541,143$ & 100.0 \\
\hline
\end{tabular}

Source: Australian Bureau of Statistics. Special table provided to the author, 21 June 2018.

Note 1: Numbers do not add precisely due to ABS randomisation process.

Note 2: Persons may change their visa type between arrival and departure thus affecting the net figure. The relatively large net figure for "Other Temporary" mainly reflects people who left Australia when they were on a Bridging visa although they had arrived on some other temporary visa. 


\section{Asians in the Main Migration Flows}

\section{Skilled Permanent}

The final stage in the discussion is to consider the Asian component of Australian migration movements. The Department of Home Affairs (and its predecessors) regularly publishes data on country of citizenship for the main visa grant categories. In relation to grants of permanent residence in the three main permanent migration streams, citizens of Asian countries made up $62.1 \%$ of the Skilled Stream and $62.5 \%$ of the Family Stream over the nine-year period from 2006-07 to 2014-15. The proportion of Asians has been increasing across time such that, in 2014-15, Asian citizens constituted $67.2 \%$ of the Skilled Stream, $67.3 \%$ of the Family Stream and $88.7 \%$ of the off-shore Humanitarian Stream. As described above, grants in the Skilled Stream are largely grants onshore to persons who arrived on a temporary visa, most often, to those who arrived on an international student visa.

\section{Family Permanent}

In the Family Stream, three factors are associated with the high percentage of grants to Asians. First, many persons already granted permanent residence in the Skilled Stream are young and single and, later, they bring in a partner from their home country. Many people in the Humanitarian Stream also bring in partners through the Family Stream. Second, many men who are Australian citizens source their brides in Southeast Asian countries. At the 2016 Census, among persons aged thirty to fifty-nine years born in Southeast Asia, there were 148 women for every 100 men. For persons of this age range born in Thailand, there were almost 300 women per 100 men. Among persons in the same age range born in China, there were 142 women for every 100 men. This last result partly reflects the predominance of women among Chinese students in Australia. Third, because of the one-child policy in China, many migrants from China to Australia are eligible to bring their parents to Australia under the longstanding criterion that a majority of the parents' children live in Australia.

\section{Temporary Movements}

From 2005-06 to March 2018, two-thirds of all international student visa grants were made to people from Asian countries. About $16 \%$ of international students move on to permanent residence in Australia (Department of Home Affairs and Department of the Treasury, 2018). However, among university students, the category most likely to proceed to permanent residence in the Skill Stream, the Asia proportion of grants in the same period was $83 \%$, rising to $87 \%$ in the recent period, 2016-17 to March 2018.

The predominance of Asian citizens among the main temporary visa holders in Australia is shown in table 2. Persons on Bridging visas are very largely persons awaiting the outcome of an application for permanent residence $(78 \%$ Asian). Those on the Temporary Graduate visa are international students who have completed their course but have opted to remain in Australia and seek employment. This is indicative of a desire to remain permanently in Australia (88\% Asian). Those who arrived as an international student are in the category most likely to be counted into the Australian population (Table 1), and they are by 
far the largest category in table 2 ( $82 \%$ Asian). The large numbers in these three visa categories and the high proportions who are Asian citizens indicates that the predominance of Asians in the Australian permanent migration programme is very likely to continue in coming years.

While only a bare majority of those on a Temporary Skilled visa are Asian citizens $(52.5 \%)$, a survey of persons on 457 visas showed that Asians were more likely to have an intention to remain in Australia on a permanent basis than those who came from non-Asian countries (Khoo et al., 2007).

Through a special tabulation provided to the author by the Australian Bureau of Statistics, it is possible to breakdown the net overseas migration movements shown in table 1 into countries of citizenship. Here the interest is in the movements of persons with an Asian country citizenship. Figure 3 shows Net Overseas Migration divided into three components: students from Asia, other Asians and other persons (non-Asians) for the years from 2004-05 to 2015-16. Over the full twelve-year period, Asian citizens made up $62 \%$ of NOM, however, in the most recent three years shown in the figure, Asian citizens constituted 77, 86 and $84 \%$ of NOM respectively. Asian citizens as a percentage of NOM fell below $50 \%$ only for the two years, 2010-11 and 2011-12, in the aftermath of the global financial crisis and also the 2010 policy change that made it near to impossible to move from a short course in Australia to a successful permanent residence application.

Finally, in relation to the central argument of the paper, figure 4 shows the arrivals, departures and net movement of students who were citizens of Asian countries across the twelve-year period from 2004-05 to 2015-16. Over a million students who were citizens of Asia were counted into the Australian population over this twelve-year period and only 361,000 were counted out of the population. Net migration of students who were Asian citizens averaged 57,000 per annum but this number has fluctuated considerably across the years from a high of 110,000 in 2008-09 (due to the high intake of short-course students from South Asia who remained long enough to be counted into the population) to a low 19,000 in 2011-12 (following the global financial crisis and the crackdown on short courses as a pathway to permanent residence). In the most recent year, 2015-16, a new high point of 74,000 net migration was reached, 30,000 being from Chinese Asia and 31,000 from South Asia.

Table 2: Temporary Residents in Australia at 31 March 2018, by Visa Subclass, Asian Citizens and Total

\begin{tabular}{lccc}
\hline Temporary Visa Type & Asian Citizen & Total & \% Asian \\
\hline Student & 436,502 & 535,811 & 81.5 \\
Bridging & 152,170 & 194,875 & 78.1 \\
Temporary Resident (Skilled) & 79,577 & 151,596 & 52.5 \\
Working Holiday Maker & 48,572 & 148,124 & 32.8 \\
Temporary Resident (Other) & 76,584 & 110,314 & 69.4 \\
Temporary Graduate (485) & 57,416 & 65,246 & 88.0 \\
OtherTemporary & 3,854 & 4,662 & 82.7 \\
\hline TOTAL & 797,259 & $1,145,382$ & 69.6 \\
\hline
\end{tabular}

Source: Derived by author from Department of Home Affairs, bp0019 temporary residents in Australia at 31 March 2018, pivot table. 
Figure 3: Components of Net Overseas Migration (Australia, 2004-05 to 2014-15)

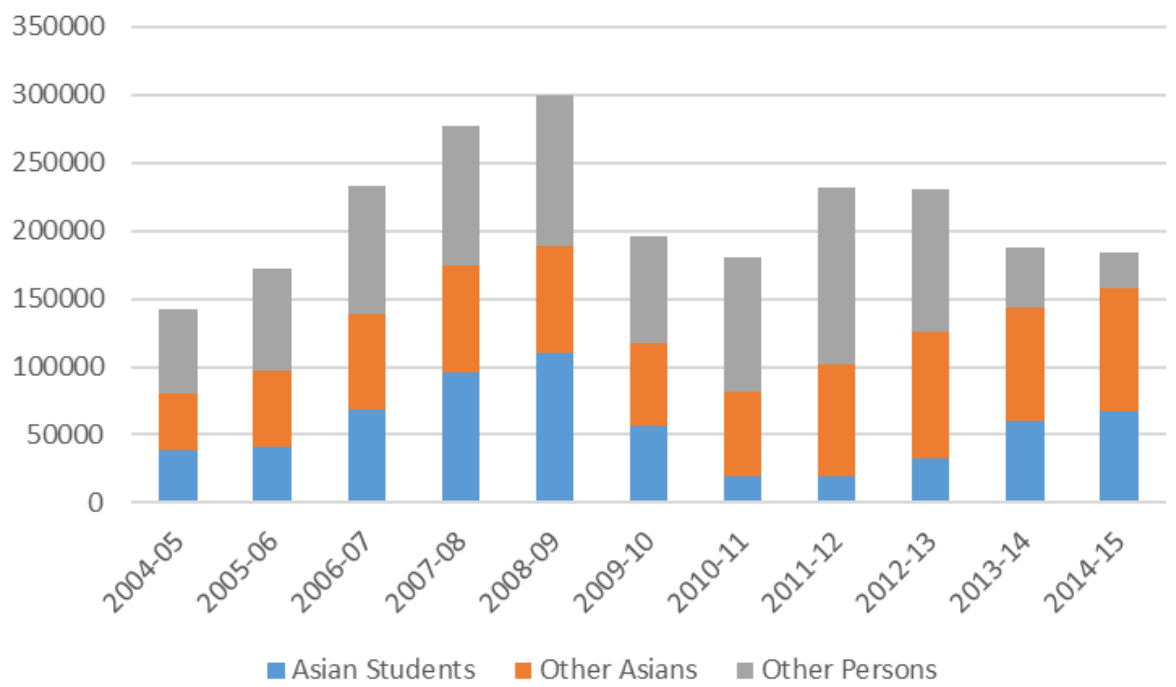

Source: Special tabulation provided to the author by the Australian Bureau of Statistics 21 June 2018.

Figure 4: Arrivals and departures of students who were citizens of Asian countries who were counted into or out of the Australian population (those who stayed in or out of Australia for twelve out of the subsequent sixteen months, 2004-05 to 2015-16)

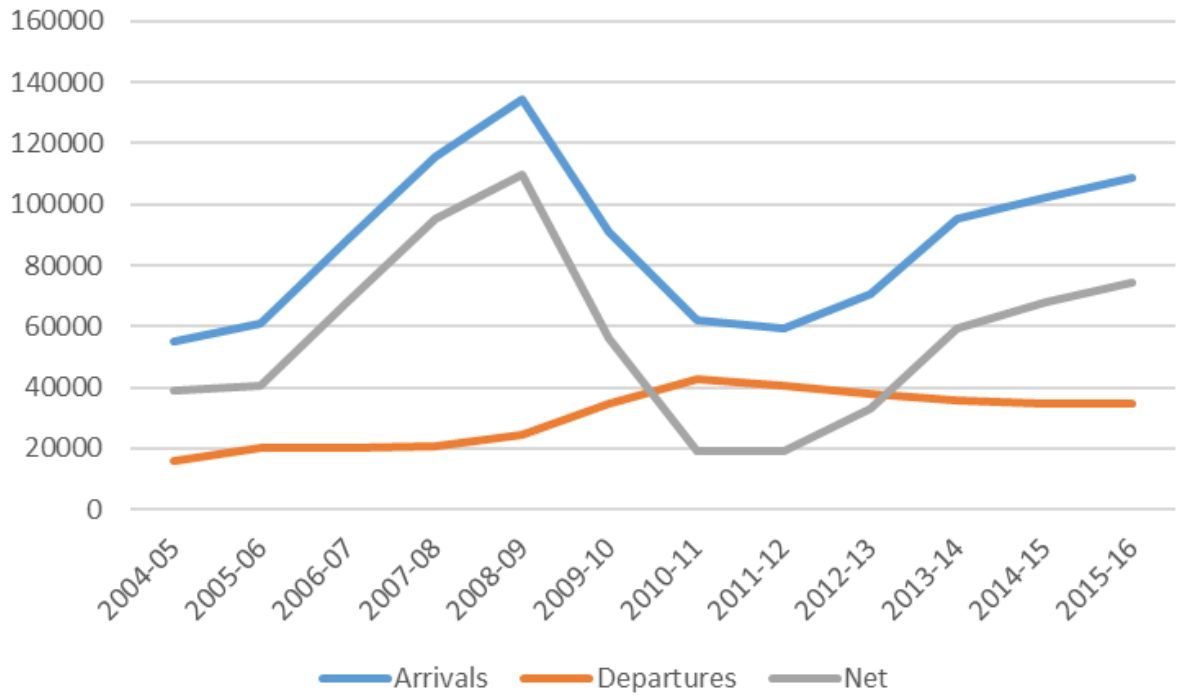

Source: Special tabulation provided to the author by the Australian Bureau of Statistics 21 June 2018. 


\section{Conclusion}

The paper has documented the degree to which international migration to Australia has come to be dominated by Asian sources and the rapid increase in the proportion of the Australian population that has Asian origins. It has also been argued that these outcomes were unintended consequences of shifts in migration policy, particularly the rise of the international student population as the main source of Australian immigrants. Indeed, given John Howard's stance on Asian migration in the late 1980s, there is an irony in the fact that the unintended consequence of rapidly increasing levels of Asian migration to Australia has been the result of policy changes set in train by the Howard Government.

While Net Overseas Migration consists of numerous movements, many of which are temporary movements, in the longer term, Net Overseas Migration is driven by the level of the government's permanent migration programme. In turn, the level of the permanent programme is driven by political decisions that are made on an annual basis. Thus, the future of Asian migration to Australia is contingent upon the annual setting of the Migration Programme level. The principal driver of the Migration Programme level is perceived labour demand relative to supply.

A recent report on future job openings in Australia for the years, 2017-2024, predicts very substantial labour demand in these years (Shah and Dixon, 2018). In an economy with a total of around 12 million employed persons at the beginning of 2017, job openings in the eight-year period are estimated to be 4.1 million, consisting of 1.9 million driven by expansion of demand and 2.2 million by replacement of workers leaving their jobs - mainly the retirements of the large baby-boom generation. This is very substantial demand. McDonald (2017) has also shown that the net increment to the number of employed persons in the period from 2011 to 2016 was made up (83\%) by immigrants who arrived in Australia in that five-year period, that is, there is little capacity for non-immigrant Australians to fill the expected large labour demand. So long as these realities are recognised by the government, it can be expected that the Migration Programme level will remain around the present level.

If the logic of the previous paragraph prevails, it can be expected that even higher percentages of future migration levels will be met by migrants from Asia as has been the case in the past three years. This can be predicted on the basis that the Asian student population in Australia is currently at its highest level ever and the Temporary Graduate (subclass 485 ) visa will be open to most of these students as a major pathway to permanent residence in Australia in the Skill Stream. There are then flow-on effects from new immigrants in the Skill Stream to the Family Stream and direct flows to the Family Stream when international students partner with Australian citizens.

A caveat to this argument is that the Shah and Dixon (2018) study shows that $55 \%$ of the job openings for the years 2017-2024 will be in occupations that are below (less skilled) than the major classes of occupation that are open to international migration in the Skill Stream. Thus, Australia will need to find large numbers of lower skilled workers. Two policy options include promoting higher employment rates among older Australians and providing the basic 
skills to unemployed Australians to enable them to take up these openings. The Humanitarian Programme offers a third alternative. Continuing difficulties associated with the Syrian and Rohingya peoples are likely to lead to the Humanitarian Programme being dominated by refugees from Asia.

This all points to further increases in the proportion of the Australian population that will have Asian origins. Since 1947 when the Australian population consisted almost entirely of persons of British origin, the nature of the population has been changing. Australia has adapted well to its increasingly multicultural population with people from every country in the world co-existing in relative harmony. For this situation to continue as Australia's population continues to diversify especially in the direction of persons with Asian origins, broad social acceptance of this change in the nature of the Australian population is necessary.

\section{References}

Australian Bureau of Statistics (ABS) (2017) Births Australia 2016, Data Cubes, Table 6. ABS Catalogue No. 3301.0, Canberra, ABS.

Choi C. Y. (1975) Chinese Migration and Settlement in Australia, Sydney, Sydney University Press, $129 \mathrm{p}$.

Commonwealth Bureau of Census and Statistics (1967) Census of the Commonwealth of Australia, $30^{\text {th }}$ June, 1961, Volume VIII - Australia, Statistician's Report, Canberra: Commonwealth Bureau of Census and Statistics.

Department of Education and Training (2015) Financial Report of Higher Education Providers, Canberra, Department of Education and Training.

Department of Home Affairs (2018) Student Visa and Temporary Graduate Visa Program Report, ending at 30 June 2018, Canberra, Department of Home Affairs.

Department of Immigration and Border Protection (2017) 2016-17 Migration Programme Report, Canberra, Department of Immigration and Border Protection.

Department of Parliamentary Services (2016) Overseas students: immigration policy changes 1997-2015, Parliamentary Library, Research Paper Series, 2015-16, Canberra, Department of Parliamentary Services.

Department of the Treasury and Department of Home Affairs (2018) Shaping a Nation: Population Growth and Immigration OverTime, Canberra, Department of the Treasury and Department of Home Affairs.

Dorling Philip (2017) Still Anti-Asian? Anti-Chinese? One Nation policies on Asian immigration and multiculturalism, Canberra, The Australia Institute, [online]. URL: https://www.tai.org.au/content/still-anti-asian-anti-chinese-one-nation-policies-asian-immigration-and-multiculturalism

Hawthorne Lesleyanne (2010) How valuable is "two-step migration"? Labour market outcomes for international student migrants to Australia, Asian and Pacific Migration Journal, 19 (1), pp. 5-36.

Howard John (2010) Lazurus Rising, Sydney, HarperCollins, 512 p.

Khoo Siew-Ean, McDonald Peter, Voigt-Graf Carmen and Hugo Graeme (2007) A global labor market: factors motivating the sponsorship and temporary migration of skilled workers to Australia, International Migration Review, 41 (1), pp. 479-509. 
Markus Andrew (2001) Race: John Howard and the Remaking of Australia, Sydney, Allen and Unwin, 288 p.

McDonald Peter (2017) International migration and employment growth in Australia, 2011-2016, Australian Population Studies, 1 (1), pp. 3-12.

Oakman Daniel (2002) "Young Asians in our homes": Colombo Plan students and White Australia, Journal of Australian Studies, 26 (72), pp. 89-98.

Pasquarelli John (1998) The Pauline Hanson Story, By the Man Who Knows, Sydney, New Holland, 338 p.

Ramsey Alan (2006) The lost art of crossing the floor, The Sydney Morning Herald, 4 December, [online]. URL: https://www.smh.com.au/national/the-lostart-of-crossing-the-floor-20060812-gdo5rd.html

Shah Chandra and Dixon Janine (2018) Future Job Openings for New Entrants by Industry and Occupation, Adelaide, NCVER, [online]. URL: https://www.ncver. edu.au/research-and-statistics/publications/all-publications/future-job-openingsfor-new-entrants-by-industry-and-occupation 


\section{Peter McDonald}

\section{Migration to Australia: From Asian Exclusion to Asian Predominance}

In a relatively short period, Australia has shifted from being a country where migration from Asia was heavily restricted under the White Australia Policy to one where most of the immigrants arriving in a very large migration programme are from Asia. The paper traces this transition and demonstrates the central role that the international student programme has played in this process of change in the twenty first century.

\section{Migration vers l'Australie : de l'exclusion des Asiatiques à leur prédominance}

En relativement peu de temps, l'Australie est passée d'un pays où la migration en provenance de l'Asie était fortement limitée par la politique de l'Australie blanche à un pays où la plupart des immigrants arrivant dans le cadre d'un très vaste programme de migration viennent d'Asie. L'article retrace cette transition et démontre le rôle central que le programme des étudiants étrangers a joué dans ce processus de changement au XXle siècle.

\section{Migración a Australia:}

de la exclusión de los asiáticos a su predominio

En un período de tiempo relativamente corto, Australia ha pasado de ser un país donde la migración de Asia estaba severamente limitada por la política de los blancos australianos a un país donde la mayoría de los inmigrantes que llegan como parte de un programa de migración muy grande provienen de Asia. Este artículo traza esta transición y demuestra el papel central que el programa de estudiantes internacionales ha desempeñado en este proceso de cambio en el siglo XXI. 